is again mixed with ammonia vapour, and in this way a continuous circulation of hydrogen between these two vessels is maintained. No hydrogen can remain in the generator while the apparatus is working, as it would be expelled by the ammonia vapour.

The return of the strong absorption liquid, from the bottom of the absorber to the generator, is provided for in a very simple way. The pipe $(7-8)$ acts as an effective 'thermo-syphon,' by means of which the strong liquid is automatically transferred back into the upper part of the generator. The heat supplied not only lifts the liquid from the level in the absorber to the higher level in the generator, but also again releases the ammonia from the water to pursue its cycle.

It will be noticed that the weak solution when leaving the lower part of the generator is practically free from ammonia on account of the high temperature prevailing.

The pipes (5) and (II), being placed inside another, act as a heat exchanger on the counterflow principle. By means of this, the hot weak liquid, which flows from the bottom of the generator into the absorber, is precooled by the comparatively cold, strong liquid that flows from the absorber to the thermo-syphon. This solution is at the same time pre-heated before entering the generator.

A test was recently made at the National Physical Laboratory on behalf of Messrs. Electrolux Ltd. (I53-I55 Regent Street, W.I), of a small refrigerator based on the above principle. The plant supplied was built into an insulated cabinet. The generator and heat interchanger were insulated with cork. The evaporator was surrounded by a metal tank projecting into the cabinet. In the test, the evaporator tank was insulated with a layer of granulated cork. Into the tank was inserted a propeller and an electric immersion heater and thermometer. The plant was set running and the energy required in the immersion heater to maintain the tank and its contents at $-5^{\circ} \mathrm{C}$. was determined by trial. Then the heat abstracted by the plant under these conditions is the sum of the energy dissipated in the immersion heater and that conducted into the tank through the cork insulation. The tests were repeated at several values of the cooling water temperature.

The correction for the heat conducted into the tank was determined as follows :-After the temperature had been maintained at $-5^{\circ} \mathrm{C}$. for some time, the plant was switched off, and the rate of rise of temperature of the stirred liquid in the tank was observed for a considerable period. By extrapolation back of the rate of rise at various temperatures, the value of $-5^{\circ} \mathrm{C}$. was deduced. The heat capacity of the tank and its contents was then determined by the electrical method, the temperature rise from an initial steady temperature, due to the generation of a known quantity of heat, being measured, when the plant was not working. This, together with the rate of rise of temperature at $-5^{\circ} \mathrm{C}$, gives data for the rate of leakage of heat at that temperature.

The table below summarises the results.

$$
\text { TANK AT }-5^{\circ} \mathrm{C} \text {. }
$$

Electrical input in heating coil, 300 watts.

\begin{tabular}{|c|c|c|c|c|}
\hline $\begin{array}{c}\text { Inlet } \\
\text { teniperature } \\
\text { of cooling } \\
\text { water. } \\
\left(^{\circ} \mathrm{C} .\right)\end{array}$ & $\begin{array}{c}\text { Air } \\
\text { temperature. } \\
\left({ }^{\circ} \mathrm{C} .\right)\end{array}$ & $\begin{array}{l}\text { Heat } \\
\text { dissipated in } \\
\text { tank around } \\
\text { evaporator. } \\
\text { (Kilo. cal. } \\
\text { per hr.) }\end{array}$ & $\begin{array}{c}\text { Heat } \\
\text { leakage } \\
\text { into tank. } \\
\text { (Kilo. cal. } \\
\text { per hr.) }\end{array}$ & $\begin{array}{c}\text { Total } \\
\text { refrigeration } \\
\text { effect. } \\
\text { (Kilo. cal. } \\
\text { per hr.) }\end{array}$ \\
\hline $7 \cdot 35$ & $8 \cdot 6$ & $5^{8 \cdot I}$ & $39 \cdot 6$ & $97 \cdot 7$ \\
\hline 11.95 & $8 \cdot 75$ & 47.5 & 40.9 & $88 \cdot 4$ \\
\hline $17 \cdot 4$ & 8.8 & $37 \cdot I$ & $4 \mathrm{I} \cdot 4$ & $7^{8 \cdot 5}$ \\
\hline
\end{tabular}

Hence it will be observed that at a cooling water temperature of $\mathrm{I} 74^{\circ} \mathrm{C}$., a total refrigeration effect of 78.5 kilo. cal. per hour is obtained for an expenditure of 258 kilo. cal. per hour in the form of electrical energy.

An ideal heat engine working between the same temperature limits and supplied with the equivalent amount of energy would give a refrigeration effect of 3090 kilo. cal. per hour.

Whether this simple ingenious machine will solve the problem of the domestic refrigerator time alone can tell. It must be realised that it is essentially an absorption type machine and, in spite of sixty years of development, this type of machine has failed to hold its own against the compressor type in the larger sized units, except where waste steam is available. An annoying trait in the older machines was the tendency for water vapour to be carried over and accumulate as ice in the evaporator.

\title{
Science in Antiquity. ${ }^{1}$
}

\author{
By Dr. J. Newton Friend.
}

$\mathrm{M}^{\mathrm{s}}$ $\mathrm{AN}$ is a curious creature, at once apprehensive and superstitious. His early observations were so closely interwoven with imagination that from his records it is oft-times difficult to sift out the wheat from the chaff.

It is to Egypt that one naturally turns for the early history of science. Learning was concentrated in the temples and in the royal courts. Magicians and necromancers were intimately associated with the ruling spirits. This is well illustrated by a story in

${ }^{1}$ Substance of a Iecture delivered by the author at the Royal Institution on June xo.

NO. 2963 , VOL. I I 8$]$ the Westcar Papyrus, concerning Seneferu, the first king of importance in the Fourth Dynasty, circa 3 I00 B.C., and the immediate predecessor of Khufu or Cheops, the builder of the Great Pyramid. It appears that upon one occasion the king was sad, and refused to be comforted by his nobles. So the magician Tchatcha-em-ankh was sent for, who advised the king to indulge in a row on the lake with a bevy of beautiful virgins. Whilst basking in the sunshine one of the maidens accidentally dropped a turquoise ornament into the water. The king, becoming acquainted with the loss, called the magician and asked him to recover 
the precious thing; whereupon Tchatcha-em-ankh spoke words of power, the waters of the lake heaped themselves up on one another, and the dry bed of the lake appeared with the ornament resting in the middle. This was recovered, and Tchatcha-em-ankh again spoke words of power, the waters fell back, and all was again as before. That Moses should be credited with having performed a similar miracle by making a pathway through the sea when leading the Hebrews out of Egypt need occasion no surprise. The power of a deity was measured by that of his priests, and, in the opinion of the Hebrews, Moses was no whit inferior to the followers of Amen or of Ra.

It is worthy of note that although commerce and religion demanded the use of balances in very early days, it was only about a hundred and fifty years ago that the value of the balance was generally recognised as a necessary adjunct to the systematic study of chemistry. In the Egyptian "Book of the Dead " the heart of the deceased is figured as being weighed in the Judgment Hall of Osiris, the counter-weight being truth, as typified by the ostrich feather. The balance bears an indicator, the movement of which, observed by Anubis, the Jackal-headed god of the Tomb or of embalmment, is recorded by Thoth, the Ibis-headed god, inventor of writing and science.

A similar idea of weighing good and evil runs through the Old Testament; as witness Belshazzar, who, we are told, was weighed in the balances and found wanting. It was regarded as grossly impious to use unjust weights and balances. In Hebrews ix. 4 we learn that the Ark contained Aaron's Rod, a Golden Pot, and two stones engraved with the Ten Commandments. Petrie very aptly suggests that these may have constituted the recognised Hebrew standards of length, volume, and weight respectively, which would naturally be kept under priestly control. In the Koran, written circa A.D. 600 , the writer is evidently familiar with the conception of accurate weighing. Thus in Sura xxi. we read that "Just balances will be set up for the day of the resurrection, neither shall any soul be wronged in aught; though were a work but the weight of a grain of mustard seed, we would bring it forth to be weighed." About this time the Arabs appear to have had excellent balances, and some of their glass coin weights, dating back to the eighth century, have been tested in recent years and found to be remarkably accurate. Thus, three weights corresponded to $32.662,3^{2} \cdot 665$, and 32.667 grains respectively, a truly wonderful agreement (see NATURE, I925, I I 5, 963).

In A.D. II2I an Arab, Al-Khazini by name, discussed the balance in a work entitled the "Book of the Balance of Wisdom," and gave the density of lead as II.33. Modern values range from II.33 to $\mathrm{II} \cdot 35$. Further, it is interesting to note that $\mathrm{Al}$ Jildaki, who died about A.D. 1360 , stated that "substances do not react except by definite weights." A short step further and Dalton's law would have been discovered and a bridge erected over a gulf of some four hundred and fifty years.

The ancient Druids of Cæsar's time were an intelligent set of men whose schools appear to have been famous amongst the Gauls. So great was their renown that young men came over to Britain from the continent to receive instruction at first hand from them. England was the Charlottenburg of western Europe. We have too often been led to despise the Druid, who is supposed to have burned his victims wholesale in wicker cages. Even if he did, he was but in keeping with the spirit of the times. Such a death would be less lingering than crucifixion, as practised by the Romans ; and certainly no more painful than the cruel Assyrian practice of flaying alive, as illustrated on their monuments.

For many reasons we may be proud of the Druids. Amongst other things they studied astronomy. To this end clocks were necessary. In the East, sun-dials were used by day and the stars by night, to tell the time; but in a climate such as that of Britain, clocks independent of the weather were a necessity. The Egyptians had two types of water-clock, but both were based on the principle that water falling into a vessel at a constant rate will uniformly raise a float, the upward movement of which is directly proportional to the time. British water-clocks, as recently shown by R. A. Smith of the British Museum, differed entirely in principle from the above, and were probably a British invention. The clock consisted of a small bronze bowl through the bottom of which a small hole was made, as in a modern flower-pot. This vessel was then floated on water in a large bronze bowl, the water slowly entering through the hole, and eventually causing it to sink. The clock appears to have been attended constantly by a slave, who would perhaps call out or strike a gong every time the vessel sank, thereby recording the time, much in the same way as the watchmen many centuries later called out the hours of the night. Vessels of bronze, somewhat resembling fryingpans, have been found in association with the bowls, and these are believed to have served as gongs for the purpose mentioned.

Alchemy may be viewed as a link between ancient and modern science. It was regarded as a divine gift, but this is not surprising when it is remembered that knowledge was mostly vested in the monasteries, and thus intimately connected with devotion. Early recipes frequently postulate that a decoction shall be heated up or otherwise treated during the recitation of a certain number of paternosters. This, of course, was to ensure that proper time was allowed for the necessary reactions to take place, and incidentally throws an interesting light on the monkish conception of time. From this it was but a short step for the superstitious to believe, or for the quack to declare, if an experiment failed, that the cause lay in lack of devotion rather than in ordinary material experimental error.

Assisting this confusion of ideas there was also a curious mystic effect due to the contact of East with West. The Eastern mind is wildly imaginative, revelling in figures of speech and parables. The more matter-of-fact Westerner, on coming into contact with Eastern science, derived, it is true, much information that was valuable, but also accepted at its face value much that was purely mystical. It was not until the time of Boyle that he was able to shake himself free from its fetters, to study Nature from a less prejudiced point of view, and thus to enter into the realm of modern science.

NO. 2963 , VOL. I I 8$]$ 